\title{
The psychological skills of basketball athletes: Are there any differences based on the playing position?
}

\author{
Fitri Agung Nanda*, Dimyati Dimyati \\ Department of Sport Science, Program Pascasarjana, Universitas Negeri Yogyakarta. \\ Jalan Colombo No. 1, Karangmalang, Yogyakarta 55281, Indonesia. \\ * Corresponding Author. Email: fitriagungnanda16@gmail.com \\ Received: 25 May 2019; Revised: 29 July 2019; Accepted: 1 August 2019
}

\begin{abstract}
Player-based psychological skills are an important factor that any coach should understand. Unfortunately, up to date there has not been any study that deals with the disclosure of player-based psychological skills especially for basketball athletes. Therefore, through the conduct of the study the researchers would like to identify the psychological skills of basketball athletes based on the playing position namely forward, guard and centre. The nature of the study is a quantitative-descriptive research with the retrospective causalcomparative design or ex-post factor design. Then, during the conduct of the study the researchers selected 24 basketball athletes who consisted of 11 forwards, 9 guards and 4 centres as the sample. In gathering the data, the instrument that had been implemented was the Psychological Skills Inventory for Sports (PSIS R5). After the data had been gathered, the data were analysed by means of one way-ANOVA with the support from SPSS for the calculation. The results of the study show that there are significant differences on the psychological skills of the basketball athletes based on the playing position. Furthermore, it is also found that the basketball players who occupy the forward position has higher score of psychological skills in comparison to the basketball athletes who occupy the guard position and the centre position.
\end{abstract}

Keywords: basketball athletes, psychological skills, playing position

How to Cite: Nanda, F., \& Dimyati, D. (2019). The psychological skills of basketball athletes: Are there any differences based on the playing position?. Jurnal Keolahragaan, 7(1), 74-82. doi:https://doi.org/10.21831/jk.v7i1.26360

do) https://doi.org/10.21831/jk.v7i1.26360

\section{INTRODUCTION}

The success of an athlete is influenced by several factors. In general, the factors that have been considered to influence the success of an athlete are physical, technical, tactical and psychological skills. In accordance to the statement about that the success of an athlete is influenced by the psychological factors, Weinberg \& Gould (2011) explain that not less than $50 \%$ of the success in sports is defined by the mental factors; in fact, within the sports such as golf, tennis and figure skating, the influence of the mental factors might achieve 90\%. Similarly, Middelkamp, van Rooijen, Wolfhagen, and Steenbergen (2017) explain that there is a rapid and very dramatic developing on the use of self-efficacy intervention toward the achievement that should be achieved among the members of a fitness club. Other psychological skill, such as motivation, has significant influence on anxiety and tactical performance indicators. As a result, psychological skills are considered important to be included into the training program for achieving the success among the athletes (Menegassi et al., 2018).

Furthermore, Farias-Junior et al. (2019) explain that there is a difference among the players with achievement in soccer when they compare their physiological and psychological response toward the session of low volume-high intensity interval training (LV-HIIT) and the different duration of performance recovery. There is not any significant difference from one player to another with regards to the two responses; instead, both responses assist the players in dealing with the session of low volume-training. The only difference is found in the different performance duration. In addition, a study about motivation by Ntoumanis (2001) shows that there is not any difference between the individual sports and the team sports on the psychological skills from the perspective of motivation prior to having a game. On the contrary, the characteristics of each player in each position might pose certain differences and 
these differences thus influence the athlete performance on the field (Köklü, Alemdaroğlu, Koçak, Erol, \& Findikoğlu, 2011). The idea in the study then was tested by Tedesqui and Orlick (2015), who explored the focus of attention that the elite soccer players experienced in numerous playing position. With regards to the test, the results of the study by Najah and Rejeb (2015) conclude that there are differences on the psychological skills between the offensive players and the defensive players within soccer. Departing from the overall elaboration, it is clear that any study with regards to the differences on the playing position within basketball certainly implies different psychological skills from one player to another (Pion et al., 2018).

For basketball athletes, every playing position has different characteristics. In relation to the different characteristics of the playing position, the aspects of psychological skills that might have been identified are namely motivation, selfconfidence, self-efficacy and imagery. Then, the significant psychological skills are observed based on the playing position on the aspects of aggressiveness, pudency, interpersonal passiveness, low positive emotion and inefficiency (Tayari, Kamkary, Roohi, \& Shokrzade, 2012). Delextrat and Kraiem (2013) explain that the presence of anxiety among the basketball players might be assessed based on the heart rate in relation to their playing position. Similarly, te Wierike, Elferink-Gemser, Tromp, Vaeyens, and Visscher (2015) explains that every position has differences in performing the ball arrangement and the self-regulation during a game. Sood (2017) further asserts that there have been significant differences on the psychological skills of the basketball players based on the playing position. Specific to the case of the study, the intended playing position is guard, forward and centre. During the development of a basketball game, there are three positions that should be given special position namely guard, forward and center (Kryeziu \& Asllani, 2016).

Departing from the review in the previous studies toward the athlete psychology and the playing position in basketball, the researchers have found that every position that a basketball player occupies display differences in terms of psychological skills. Therefore, through the study the researchers would like to identify the presence or the absence of the psychological skills among the basketball athletes based on the playing position. The findings and the differences that have been found in the study will be disclosed more comprehensively and the disclosure later will include the aspects of motivation, self-confidence, anxiety control, team significance and concentration based on the playing position in the basketball game.

\section{METHOD}

Within the conduct of the study, the method that had been implemented was the quantitative descriptive method while the type of the study was the retrospective causal-comparative design or also known as ex-post facto design. The selection of both the method and the technique was that the objective of the study had been to identify the presence or the absence of the psychological skills among the basketball athletes based on the playing position. The instrument that had been implemented in the study was the Psychological Skills Inventory for Sports (PSIS R-5). This instrument had been adopted from Mahoney, Gabriel, and Perkins (1987) and consisted of 44 items that disclosed 6 aspects of psychological skills namely 8 items of Motivation, 8 items of Self-Confidence, 8 items of Anxiety Control 6 items of Mental Preparation, 7 items of Team Significance and 7 items of Concentration. The instrument that had been implemented also referred to Tenenbaum, Eklund, and Kamata (2012) and was validated in order to be adjusted to the language and the use in the study. The instrument was also assessed by three rates from the domain of language, sport psychology and materials. After the assessment had been performed, the instrument was administered to 76 athletes who had similar characteristics. After the overall data had been attained, the researcher ran the one way-ANOVA analysis in order to disclose the comparison on the psychological skills of the basketball players based on the playing position. The data then were analysed by means of SPSS Version 22 Software.

The study itself took place for six months, starting from the permit processing to the Indonesia Asian Games Organizing Committee (INASGOC), which had been the organizing committee of Asian Games, up to the data gathering activities from the basketball athletes of Asian Games in Jakarta. The INASGOC facilitated the researchers by distributing the research instrument to the athletes and meeting the needs for the data gathering activities. Then, the INASGOC suggested the researchers to hold a meeting with the National Olympic Committee (NOC) - Indonesian Representatives. After holding a meeting with the National Olympic 
Committee (NOC) - Indonesian Representatives, the researchers were directed to meet again the NOC Assistant who directly handled the basketball games. During the data gathering activities, the researchers were prohibited to meet the basketball athletes directly. Instead, the researchers were accompanied by the NOC Assistant. In this occasion, the NOC Assistant distributed the instrument to the basketball athletes because the athletes had tight schedules. The data gathering activities were performed when the athletes took their resting time in the Athletes Village (AV) during the Asian Games for five days (from September $2^{\text {nd }}$ until September $4^{\text {th }}, 2018$ ). Prior to completing the instrument, the basketball athletes were shortly briefed about the objective and the significance of the instrument completion; in the brief, it was emphasized that the instrument should be completed in a fair manner according to the psychological conditions of the athletes. After the overall data that had been gathered, the researcher clarified the data of the psychological skills from the basketball athletes. The total number of the sample was 24 basketball athletes from the Indonesian National Basketball Athletes who played in the $18^{\text {th }}$ Asian Games 2018 iun Jakarta. The composition of the 24 basketball athletes was 12 male athletes and 12 female athletes and the mean of the athletes' age was 22.80 years old. Based on the playing position, the respondents were divided into 11 forwards, 9 guards and 4 centres.

\section{RESULTS AND DISCUSSIONS}

In this section, the researchers will elaborate the results that have been attained from the data gathering activities. Afterward, the researchers will discuss these results based on the objective of the study namely to identify the presence or the absence of psychological skills among the basketball athletes during a game based on the playing position.

\section{Results}

The reliability and the validity test results for the instrument of psychological skills might be consulted in Table 1. For Motivation, the validity score is 0.679 while the reliability score is 0.792 . Then, for Self-Confidence the validity score is 0.636 while the score reliability is 0.775 . Next, for Anxiety Control the validity score is 0.779 while the reliability score is 0.914 . Afterward, for Mental Preparation the validity score is 0.839 while the reliability score was 0.803 . Last but not the least, for Concentration the validity score is 0.731 while the reliability score is 0.856 .

On the other hand, the athlete demography that has been implemented in the study contains the personal data of the athletes. The personal data discuss more about the athlete's playing position, sex, height and weight, age and basketball club of origin from the athletes who have joined the Indonesian National Basketball Team for the Asian Games XVIII 2018. The data of the athlete demography might be consulted in Table 2.

The results in Table 2 show that from 24 basketball athletes in the Indonesian National Basketball Team for the Asian Games XVIII 201812 athletes are male and 12 athletes are female. Then, in terms of playing position 9 athletes are guards, 11 athletes are forward and 4 athletes are centres. Then, the height of the 24 basketball athletes is various namely: (a) $165 \mathrm{~cm}$ (1 athletes); (b) $167 \mathrm{~cm}$ (2 athlete); (c) $170 \mathrm{~cm}$ (1 athlete); (d) $171 \mathrm{~cm}$ (1 athlete); (e) $173 \mathrm{~cm} \mathrm{(2}$ athletes); (f) $175 \mathrm{~cm}$ (1 athlete); (g) $176 \mathrm{~cm} \mathrm{(1}$ athlete); (h) $177 \mathrm{~cm}$ (1 athlete); (i) $178 \mathrm{~cm}$ (1 athlete); (j) $179 \mathrm{~cm}$ (one athlete); (k) $180 \mathrm{~cm}$ (1 athlete); (1) $181 \mathrm{~cm}$ (1 athlete); (m) $184 \mathrm{~cm} \mathrm{(2}$ athletes); (n) 1 athlete $(187 \mathrm{~cm}) ;$ (o) $190 \mathrm{~cm} \mathrm{(1}$ athlete); (p) $191 \mathrm{~cm}$ (1 athlete); (q) $193 \mathrm{~cm} \mathrm{(1}$ athlete); (r)195 cm (1 athlete); (s) $196 \mathrm{~cm}$ (1 athlete); (t) $198 \mathrm{~cm}$ (1 athlete) and (u) $202 \mathrm{~cm}$ (1 athlete).

Table 1. Instrument Validity and Reliability

\begin{tabular}{lccc}
\hline \multicolumn{1}{c}{ Psychological Skills } & $\begin{array}{c}\text { Coefficient of Validity } \\
\text { (Aiken's V) }\end{array}$ & \multicolumn{2}{c}{$\begin{array}{c}\text { Coefficient of Reliability } \\
\text { (Cronbach's Alpha) }\end{array}$} \\
\hline Motivation & & 0.679 & 0.792 \\
Self-Confidence & & 0.636 & 0.775 \\
Anxiety Control & 0.779 & 0.914 \\
Mental Preparation & 0.839 & 0.921 \\
Team Significance & 0.665 & 0.803 \\
Concentration & & 0.731 & 0.856 \\
\hline
\end{tabular}


Jurnal Keolahragaan 7 (1), 2019 - 77

Fitri Agung Nanda, Dimyati Dimyati

Table 2. Athlete Demography of Indonesian National Basketball Team for the Asian Games XVIII 2018

\begin{tabular}{|c|c|c|c|c|c|c|c|c|c|}
\hline \multirow{2}{*}{ No. } & \multirow{2}{*}{$\begin{array}{l}\text { Player's } \\
\text { Position }\end{array}$} & \multirow{2}{*}{$\mathrm{M} / \mathrm{F}$} & \multirow{2}{*}{$\begin{array}{l}\text { Height } \\
(\mathrm{cm})\end{array}$} & \multirow{2}{*}{$\begin{array}{c}\text { Weight } \\
(\mathrm{kg})\end{array}$} & \multicolumn{4}{|c|}{ Age } & \multirow{2}{*}{ Club } \\
\hline & & & & & $17-20$ & $21-24$ & $25-29$ & $30-34$ & \\
\hline 1. & Guard & $\mathrm{M}$ & 175 & 76 & & & $\mathrm{X}$ & & Pelita Jaya \\
\hline 2. & Guard & M & 180 & 77 & & $\mathrm{X}$ & & & Stapac Jakarta \\
\hline 3. & Guard & M & 181 & 81 & & & & $\mathrm{X}$ & Pelita Jaya \\
\hline 4. & Guard & M & 190 & 68 & & & & $\mathrm{X}$ & CLS Knight \\
\hline 5. & Forward & M & 191 & 103 & & & & $\mathrm{X}$ & Pelita Jaya \\
\hline 6. & Forward & M & 196 & 95 & & & & $\mathrm{X}$ & Satria Muda \\
\hline 7. & Forward & M & 184 & 88 & & & $\mathrm{X}$ & & Cls Knight \\
\hline 8. & Forward & M & 193 & 110 & & & $\mathrm{X}$ & & Pelita Jaya \\
\hline 9. & Center & M & 202 & 94 & & & $\mathrm{X}$ & & Satria Muda \\
\hline 10. & Forward & M & 195 & 91 & & $\mathrm{X}$ & & & Satria Muda \\
\hline 11. & Center & M & 198 & 108 & & & $\mathrm{X}$ & & Pelita Jaya \\
\hline 12. & Guard & M & 187 & 90 & & & & $\mathrm{X}$ & Satria Muda \\
\hline 13. & Forward & $\mathrm{F}$ & 178 & 71 & $\mathrm{X}$ & & & & Sahabat Semarang \\
\hline 14. & Forward & $\mathrm{F}$ & 167 & 60 & & $\mathrm{X}$ & & & Surabaya Fever \\
\hline 15. & Forward & $\mathrm{F}$ & 176 & 73 & $\mathrm{X}$ & & & & Surabaya Fever \\
\hline 16. & Guard & $\mathrm{F}$ & 165 & 68 & $\mathrm{X}$ & & & & Surabaya Fever \\
\hline 17. & Guard & $\mathrm{F}$ & 173 & 64 & $\mathrm{X}$ & & & & Bima Sakti Malang \\
\hline 18. & Forward & $\mathrm{F}$ & 171 & 68 & & $\mathrm{X}$ & & & Surabaya Fever \\
\hline 19. & Forward & $\mathrm{F}$ & 167 & 64 & $\mathrm{X}$ & & & & Tanago Friesian Jakarta \\
\hline 20. & Guard & $\mathrm{F}$ & 179 & 66 & & & $\mathrm{X}$ & & Surabaya Fever \\
\hline 21. & Guard & $\mathrm{F}$ & 173 & 88 & & $\mathrm{X}$ & & & Tenaga Baru Pontianak \\
\hline 22. & Forward & $\mathrm{F}$ & 170 & 62 & & $\mathrm{X}$ & & & Merpati Bali \\
\hline 23. & Center & $\mathrm{F}$ & 184 & 60 & & & $\mathrm{X}$ & & Surabaya Fever \\
\hline 24. & Center & $\mathrm{F}$ & 177 & 75 & & $\mathrm{X}$ & & & GMC Cirebon \\
\hline
\end{tabular}

On the other hand, the weight of the 24 basketball athletes in the Indonesian National Basketball Team for the Asian Games XVIII 2018 are also various. The composition of the athletes' weight are as follows: (a) $60 \mathrm{~kg}(2$ athletes); (b) $62 \mathrm{~kg}$ (1 athlete); (c) $64 \mathrm{~kg}(2$ athletes); (d) $66 \mathrm{~kg}$ (1 athlete); (e) $68 \mathrm{~kg}$ (2 athletes); (f) $71 \mathrm{~kg}$ (1 athlete); (g) $73 \mathrm{~kg}$ (1 athlete); (h) $75 \mathrm{~kg}$ (1 athlete); i) $76 \mathrm{~kg}$ (1 athlete); (j) $77 \mathrm{~kg}$ (1 athlete); (k) $81 \mathrm{~kg}$ (1 athlete); (l) 88 kg (1 athlete); (m) $90 \mathrm{~kg}$ (1 athlete); (n) $91 \mathrm{~kg}$ (1 athlete); (o) $94 \mathrm{~kg}$ (1 athlete); (p) $95 \mathrm{~kg}$ (1 athlete); (q) $103 \mathrm{~kg}$ (1 athlete); $108 \mathrm{~kg}$ (1 athlete); and $110 \mathrm{~kg}$ (1 athlete).

Furthermore, the 24 basketball athletes from the Indonesian National Basketball Team for the Asian Games XVIII 2018 are from different ages. The range of the 24 basketball athletes is as follows: (a) 17-20 years old (5 athletes); (b) $21-24$ years old (7 athletes); (c) 25 -29 years old (7 athletes); and (d) $30-34$ years old (5 athletes).

Last but not the least, the 24 basketball athletes of the Indonesian National Basketball Team for the Asian Games XVIII 2018 come from 11 basketball clubs that compete in the Indonesian Basketball League Competition. The list of the basketball clubs along with the composition of the athletes are as follows: (a) Pelita Jaya Jakarta (5 athletes); (b) Satria Muda Jakarta (4 athletes); (c) CLS Knight Surabaya (2 athletes); (d) Stapac Jakarta (1 athlete); (e) Surabaya Fever (6 athletes); (f) Sahabat Semarang (1 athlete); (g) Bima Sakti Malang (1 athlete); (h) Tanago Friesien Jakarta (1 athlete); (i) Tenaga Baru Pontianak (1 athlete); (j) Merapi Bali (1 athlete); and (k) GMC Cirebon (1 athlete). The results of the study show that there have been differences on the psychological skills of the Indonesian basketball athletes in the Asian Games XVIII 2018 in terms of playing position. These results might be consulted in Table 3 and 4 below.

Table 3. Results of One Way-ANOVA for the Psychological Skills of the Indonesian Basketball Athletes Based on the Playing Position

\begin{tabular}{lrrrr}
\hline $\begin{array}{l}\text { Sum of } \\
\text { Square }\end{array}$ & df & \multicolumn{1}{c}{$\begin{array}{c}\text { Mean } \\
\text { Square }\end{array}$} & F & Sig. \\
\hline 2313.069 & 2 & 1156.535 & 5.416 & .0137 \\
4484.556 & 21 & 213.550 & & \\
6797.625 & 23 & & & \\
\hline
\end{tabular}


Jurnal Keolahragaan 7 (1), 2019 - 78

Fitri Agung Nanda, Dimyati Dimyati

Table 4. Descriptive Data on the Psychological Skills of the Indonesian Basketball Athletes based on the Playing Position

\begin{tabular}{lrrrr}
\hline Position & N & Mean & $\begin{array}{c}\text { Std. } \\
\text { Deviation }\end{array}$ & Std. Eror \\
\hline Forward & 11 & 152.00 & 14.677 & 4.425 \\
Guard & 9 & 133.22 & 12.458 & 5.153 \\
Center & 4 & 130.50 & 19.053 & 9.526 \\
Total & 24 & 141.38 & 17.192 & 3.509 \\
\hline
\end{tabular}

Both Table 3 and Table 4 above show the calculation results that have been attained from the operation of one way-ANOVA analysis for the psychological skills of the 24 Indonesian basketball athletes in the Asian Games XVIII 2018 based on their playing position. From the results of the analysis, the researchers have found that the sig. value $=0.0137<0.05$. Consequently, the null hypothesis or Ho is rejected. Consequently, it might be concluded that there are significant differences on the psychological skills of the 24 Indonesian basketball athletes based on their playing position. The highest score of psychological skills are attained by the forwards, followed by guards and centres. The score of psychological skills for the forwards is 152.00 , while the score of psychological skills for the forward 133.22 and eventually the score of psychological skills for guards is 130.50 . Therefore, it might be safely concluded that there are differences on the psychological skills of basketball athletes based on their playing position.

\section{Discussion}

The results of the study show that there are differences on the psychological skills of the Indonesian basketball athletes based on the playing position. The number of studies on the psychological skills based on the playing position is indeed very limited but these studies point to almost similar results. For example, the results of a study by (Köklü et al., 2011) explain that the characteristics of the basketball players in their respective position display differences and have significant inlufnce on the athlete performance during the game. Similarly, (Pion et al., 2018) state that in each position basketball players will display different characteristics of performance from one to another.

Furthermore, Sampaio, Godoy, \& Feu (2004) explain that based on the game statistics basketbal players have differences from one to another in relation to their playing position since the points of observation within the game statistics are the duties of offensive, defensive, rebound, assist, point scoring, team performance and team work. The position of guard and center is more dominant on the defensive aspect, the rebound aspect and the team work aspect. On the other hand, the position of forward is more dominant on the offensive aspect and the point scoring aspect. In performing assist, the position of guard is better than the others. In the same time, the position of guard has better team work characteristics than others.

Tayari et al. (2012) explains that there are significant differences on the psychological skills of the basketball players from the aspect of aggresiveness, pudency, interpersonal passivity, low positive emoton and inefficiency. He further asserts that forwards have the highest score on all of the five aspects in comparison to guards and centres whereas guards occupy the second highest score on all of the five aspects and centres occupies the third or the last place.

Delexrat \& Kraiem (2013) explaikn that the presence of anxiety among th basketball players might be measured from their heartbeat based on the playing position. Furthermore, they explain that the position of center has more regular heartbeat and anxiety in comparison to the other positions during a game. On the contrary, the position of guard and forward does not display any significant differences on both aspects. In other words, the position of guard and forward has less regular heartbeat and anxiety in comparison to the position of center during a game.

te Wierike et al. (2015) explains that each playing position has different pace in arranging the ball and the self-control during a game. She further suggests that the position of guard and forward has better ball control in comparison to the position of center. Similarly, the position of guard and forward has better self-control than the position of center; these differences influence the performance of each playing position during a game.

Sood (2017) explains that there are significant differences among the basketball players based on the position namely guard, forward and center. The aspects that have been analysed during his study is related to the emotional intelligence, which dimension consists of SelfAwareness, Empathy, Emotional Stability, Relationship Management, Integrity and Commitment. 
Jurnal Keolahragaan 7 (1), 2019 - 79

Fitri Agung Nanda, Dimyati Dimyati

\section{Psychological Skills of Guard}

The results of the study show that there are differences among the players who have been assigned into the position of guard, forward and center. In this study, the position of guard has better psychological skills than the position of center but lower psychological skills in comparison to the position of forward. The players in the position of guard has higher concentration in comparison to the two other positions. Then, in the aspects of mental skills the position of guard and center does not indicate any significant difference. Unfortunately, the position of forward has earned the lowest score in these aspects of mental skills. Dereceli (2018) explains that thre are differences on the psychological skills among the basketball players from the aspects of concentration and of mental preparation.

The basketball players who occupy the position of a guard possess leadership characteristics and team significance in comparison to the players who occupy the position of a forward or a centre. As a guard, the basketball players should understand the personalities of their teammates and thus they should develop a kind of relationship with their teammates. Then, the basketball players who occupy the position of a guard usually have better and more stable personality and emotion level in comparison to the basketball players who occupy the other positions (Chartrand, Jowdy, \& Danish, 2016).

Guard is the position in which the height of the player is not taller than forward (Köklü et al., 2011). The position of a guard is lower and the lowest body fat percentage in comparison to a forward and a center. Kucsa \& Mačura (2015) (2015) and Nešić, Fratrić, \& Vukašinović (2013) state that guard has the highest amount of body mass and the lower height in comparison to centre.

The main objective of playing as a guard is to dribble and to pass the ball to the teammates (Khoeron, 2017, p. 36). He explains further that guard is tasked to control the game and to be the leader in the field. In the same time, guard is also tasked to distribute the ball equally to the teammates and to be responsive so that he or she can mark the teammates who are out of the opponents' marking. Similarly, (Giannini, 2009, p. 6) explains that guard should be occupied by the basketball players who have good shooting capacity but the players who occupy the other positions should also have good shooting capacity so that the point of victory might be assured.

In general, guard is occupied by the players who have defensive capacity and good steal and thus guard becomes the key player who is tasked to distribute the ball and to execute the strategies that will be implemented in the field (Dimyati, 2018 , p. 20). Then, guard has the highest $\mathrm{VO}_{2}$ Max in comparison to the other positions while center has the lowest $\mathrm{VO}_{2}$ Max (Sallet, Perrier, Ferret, Vitelli, \& Baverel, 2005). According to te Wierike, Huijgen, Jonker, Elferink-Gemser, \& Visscher (2018), guard has faster response in comparison to forward and centre. Last but not the least, guard also has better rate of speed and accuracy than the other position (Kucsa \& Mačura, 2015).

\section{Psychological Skills of Forward}

The results of the study show that there are differences among guard, forward and centre. With regards to these results, it is found that the players who occupy the position of forward has the highest score of psychological skills in comparison to the other positions. These results are in accordance to the results of the study by (Chartrand et al., 2016), which suggest that a forward usually has better self-confidence and higher focus in comparison to the other positions. During the defensive game, a forward should be under full concentration so that he or she will not commit any foul. Any basketball player who occupies this position should be clever because the position of a forward is very crucial within the defensive line in order to prevent any score that might be made by the opponent's team.

During a basketball game, a forward is required to score a point (Khoeron, 2017, p. 37). In addition, a forward is also required to take over a rebound situation when the opponent player either tries to score a point or break through the defense line. A basketball team heavily relies on this position and therefore the player who occupies the position of a forward should be able to hold the defensive line.

In general, the position of a forward is assigned to the players who are more aggressive when they break through the defensive live of the opponent team. Kucsa and Mačura (2015) explains that the position of forward has better agility in comparison to the position of guard and of centre. Furthermore, during a basketball game the position of a forward is better at rebound, defence, assist, steal and block rather than the other positions (Sampaio et al., 2004). Not to 
mention, forward is more aggressive during the defensive rebound in comparison to guard (Nešić et al., 2013).

Psychological Skills of Centre

The results of the study show that there are differences among guard, forward and centre in terms of psychological skills and that the position of centre has the lowest score of psychological skills. These results are in accordance to the results of a study by Delextrat and Kraiem (2013) which show that the rate of anxiety among the basketball players can be defined by means of heartbeat measurement. Furthermore, they explain that the position of centre usually has more regular rate of anxiety and heartbeat in comparison to the two other positions during a game. Then, the position of centre is usually occupied by the tallest player in the team. According to Nageswaran (2012), the posture of a centre is usually higher than a guard or a forward. Not to mention, in certain occasion the position of a centre is occupied by the tallest basketball player in a group (Kucsa \& Mačura, 2015). Nešić et al. (2013) suggest that a centre player usually has higher longitudinal and transversal dimension and also higher body mass in comparison to the guard player and the forward player.

The main task of a centre is to guard the opponent player so that the opponent player will not score any point (Khoeron, 2017, p. 38). This position is ultimately important because a centre will hold the very end of the defensive line in the team (Dimyati, 2018, p. 20). A centre is responsible for guarding the opponent player from shooting a point and passing the ball around the vital area. Last but not the least, a centre is expected to give his or her best during the rebound situation (Sport Singapore Council, 2019).

\section{CONCLUSIONS}

Based on the results of the study and also the discussions in the study, the researchers would like to conclude that there are differences among the basketball players in terms of psychological skills. The players in the forward position has higher score on the aspect of motivation, self-confidence, team significance, anxiety control, mental preparation and concentration in comparison to the other positions. On the other hand, the players in the centre position has lowest score on these aspects whereas the players in the forward position have the second higher score on the overall aspects.

\section{ACKNOWLEDGEMENT}

The study on the psychological skills based on the playing position has been funded by the Ministry of Research, Technology and Higher Education of the Republic of Indonesia through the Department of Research and Community Service Universitas Negeri Yogyakarta.

\section{REFERENCES}

Chartrand, J. M., Jowdy, D. P., \& Danish, S. J. (2016). The psychological skills inventory for sports: Psychometric characteristics and applied implications. Journal of Sport and Exercise Psychology, 14(4), 405-413. https://doi.org/10.1123/jsep.14.4.405

Delextrat, A., \& Kraiem, S. (2013). Heart-rate responses by playing position during ball drills in basketball. International Journal of Sports Physiology and Performance, $8(4)$, 410-418. https://doi.org/10.1123/ijspp.8.4.410

Dereceli, Ç. (2018). An examination of concentration and mental toughness in professional basketball players. Journal of Education and Training Studies, 7(1), 17. https://doi.org/10.11114/jets.v7i1.3841

Dimyati, D. (2018). Psikologi olahraga metode latihan mental bola basket. Yogyakarta: UNY Press.

Farias-Junior, L. F., Macêdo, G. A. D., Browne, R. A. V., Freire, Y. A., Oliveira-Dantas, F. F., Schwade, D., ... Costa, E. C. (2019). And psychological responses during lowvolume high-intensity interval training sessions with different work-recovery durations. Journal of Sports Science and Medicine, 18(1), 181-190.

Giannini, J. (2009). Court sense: Winning basketball's mental game. Human Kinetics.

Khoeron, N. (2017). Buku pintar basket. Jakarta: Anugrah.

Köklü, Y., Alemdaroğlu, U., Koçak, F. Ü., Erol, A. E., \& Findikoğlu, G. (2011). Comparison of chosen physical fitness characteristics of turkish professional basketball players by division and playing position. Journal of Human Kinetics, $30(1)$, 99-106. https://doi.org/10.2478/v10078-011-0077- 
$\mathrm{y}$

Kryeziu, A. R., \& Asllani, I. (2016). Differences in some motor skills of basketball positions according to to 16 year olds. Acta Kinesiologica, 10(2), 26-30.

Kucsa, R., \& Mačura, P. (2015). Physical characteristics of female basketball players according to playing position. Acta Facultatis Educationis Physicae Universitatis Comenianae, 55(1), 46-53. https://doi.org/10.1515/afepuc-2015-0006

Mahoney, M. J., Gabriel, T. J., \& Perkins, T. S. (1987). Psychological skills and exceptional athletic performance. The Sport Psychologist, 1(3), 181-199. https://doi.org/10.1123/tsp.1.3.181

Menegassi, V. M., Rechenchosky, L., Borges, P. H., Nazario, P. F., Carneiro, A. F. F., Fiorese, L., \& Rinaldi, W. (2018). Impact of motivation on anxiety and tactical knowledge of young soccer players. Journal of Physical Education and Sport, 18(1), 170-174. https://doi.org/10.7752/jpes.2018.01022

Middelkamp, J., van Rooijen, M., Wolfhagen, P., \& Steenbergen, B. (2017). The effects of a self-efficacy intervention on exercise behavior of fitness club members in 52 weeks and long-term relationships of transtheoretical model constructs. Journal of Sports Science and Medicine, 16(2), 163-171.

Nageswaran, N. (2012). Position-wise discriminating tendency among anthropometric characteristics of indian youth elite basketball player. International Journal of Scientific Research, 2(7), 1-3. https://doi.org/10.15373/22778179/july20 $13 / 189$

Najah, A., \& Rejeb, R. Ben. (2015). The psychological profile of youth male soccer players in different playing positions. Advances in Physical Education, 05(03), 161-169.

https://doi.org/10.4236/ape.2015.53020

Nešić, M., Fratrić, F., \& Vukašinović, V. (2013). Motivational characteristics of karate coaches. Facta Universitatis.

Ntoumanis, N. (2001). A self-determination approach to the understanding of motivation in physical education. British Journal of Educational Psychology, 71(2), 225-242. https://doi.org/10.1348/000709901158497

Pion, J., Segers, V., Stautemas, J., Boone, J., Lenoir, M., \& Bourgois, J. G. (2018). Position-specific performance profiles, using predictive classification models in senior basketball. International Journal of Sports Science \& Coaching, 13(6), 10721080.

https://doi.org/10.1177/174795411876505 4

Sallet, P., Perrier, D., Ferret, J. M., Vitelli, V., \& Baverel, G. (2005). Physiological differences in professional basketball players as a function of playing position and level of play. Journal of Sports Medicine and Physical Fitness, 45(3), 291-294.

Sampaio, J., Godoy, S. I., \& Feu, S. (2004). Discriminative power of basketball gamerelated statistics by level of competition and sex. Perceptual and Motor Skills, 99(3_suppl), 1231-1238. https://doi.org/10.2466/pms.99.3f.12311238

Sood, M. (2017). A comparative analysis of emotional intelligence among basketball players. International Journal of Physiology, Nutrition and Physical Education, 2(2), 626-629. Retrieved from http://www.journalofsports.com/pdf/2017/ vol2issue2/PartK/2-2-130-170.pdf

Tayari, F., Kamkary, K., Roohi, G. S., \& Shokrzade, S. (2012). The relationship between the professional female basketball players' personality profiles and their position in a play. Journal of Basic and Applied Scientific Research, 2(6), 60986107. Retrieved from https://www.textroad.com/pdf/JBASR/J.

Basic. Appl. Sci. Res., 2(6)6098-6107, 2012.pdf

te Wierike, S. C. M., Elferink-Gemser, M. T., Tromp, E. J. Y., Vaeyens, R., \& Visscher, C. (2015). Role of maturity timing in selection procedures and in the specialisation of playing positions in youth basketball. Journal of Sports Sciences, 33(4), 337-345. https://doi.org/10.1080/02640414.2014.94 2684

te Wierike, S. C. M., Huijgen, B. C. H., Jonker, L., Elferink-Gemser, M. T., \& Visscher, C. (2018). The importance and development 
Jurnal Keolahragaan 7 (1), 2019 - 82

Fitri Agung Nanda, Dimyati Dimyati

of ball control and (self-reported) selfregulatory skills in basketball players for different positions. Journal of Sports Sciences, 36(6), 710-716. https://doi.org/10.1080/02640414.2017.13 34954

Tedesqui, R. A. B., \& Orlick, T. (2015). Brazilian elite soccer players: Exploring attentional focus in performance tasks and soccer positions. Sport Psychologist, 29(1), 4150. https://doi.org/10.1123/tsp.2014-0007

Tenenbaum, G., Eklund, R. C., \& Kamata, A. (2012). Introduction to measurement in sport and exercise psychology. In Measurement in Sport and Exercise Psychology (pp. 3-7). 